Dalton : Jurnal Pendidikan Kimia dan Ilmu Kimia, Volume 2 Nomor 1, Mei 2019

\title{
STUDI KOMPARASI MODEL PEMBELAJARAN TALKING STICK DAN SNOWBALL TRHOWING TERHADAP HASIL BELAJAR SISWA PADA MATERI TATA NAMA SENYAWA KELAS X SMA NEGERI 1 ALALAK
}

\author{
The Comparison Studi of Using Talking Stick and Snowball Trhowing \\ Learning Model Towards Outcomes on Compounds Nomenclature Topic at \\ Class X SMA Negeri 1 Alalak
}

\author{
Maziah, Raden Roro Ariessanty Alicia Kusuma Wardhani, Mohan Taufiq Mashuri \\ Program Studi Pendidikan Kimia Fakultas Keguruan dan Ilmu Pendidikan \\ Universitas Islam Kalimantan (Uniska) Muhammad Arsyad Al Banjari, Banjarmasin \\ *e-mail:maziah1131@gmail.com
}

\begin{abstract}
Abstrak. Penelitian ini bertujuan untuk membandingkan hasil belajar antara siswa yang dibelajarkan dengan talking stick dan snowball throwing. Desain penelitian yang digunakan adalah nonequivalent control group design. Populasi penelitian adalah seluruh siswa kelas X SMA Negeri 1 Alalak, dan sample penelitian adalah siswa kelas X IPA 1 yang berjumlah 25 orang dan siswa kelas X IPA 2 yang berjumlah 24 orang. Teknik pengumpulan data yang digunakan adalah tes berupa pilihan ganda. Data yang diperoleh dianalisis menggunakan uji t. Hasil penelitian menunjukkan terdapat perbedaan hasil belajar antara siswa yang dibelajarkan dengan talking stick dansnowball throwing.
\end{abstract}

Kata Kunci : Hasil belajar, snowball throwing, tata nama senyawa, talking stick

\begin{abstract}
This study aimed to compare learning outcomes between students who are taught with the talking stick and snowball throwing. The research design used was nonequivalent control group design. The study population was all students of class X SMA Negeri 1 Alalak, and the study sample was students of class X IPA 1, amounting to 25 people and students of class X IPA 2, amounting to 24 people. The data collection technique used is a multiple choice test. The data obtained were analyzed using the t test. The results of the study showed that there were differences in learning outcomes between students who were taught with the talking stick and snowball throwing.
\end{abstract}

Keywords: Compound nomenclature, learning outcomes, snowball throwing, talking stick

\section{PENDAHULUAN}

Dalam suatu kegiatan belajar sangat diperlukan adanya aktivitas belajar.Tanpa adanya aktivitas, proses belajar tidak mungkin berlangsung dengan baik. Banyak jenis aktivitas yang dapatdilakukan oleh siswa di sekolah. Aktivitas siswa tidak cukup hanya mendengarkan dan mencatat seperti yang lazim terdapat di sekolah-sekolah (Sardiman, 2011: 97).

Berdasarkanhasilpengamatanselama proses pembelajaran yang dilakukan di kelas X SMAN 1 ALALAK, proses pembelajaran Kimia di SMAN 1 ALALAK masih menggunakan pembelajaran langsung, dengan menggunakan metode ceramah, dan 
masih berpusat pada guru. Selain itu, berdasarkan hasil wawancara kepada guru bidang studi kimia pada SMAN 1 ALALAK pembelajaran dengan menggunakan cara konvensional menghasilkan nilai siswa $85 \%$ dibawah KKM. Pada proses pembelajaranpun sangat sedikit siswa yang aktif dan berani bertanya jika ada yang tidak dimengerti. Ha 1 in isenada dengan pengamatan peneliti pada saat PPL 2 yaitu nilai siswa dibawah KKM danhanyasebagian siswa yang aktif pada saa tpembelajaran. Berdasarkan permasalahan tersebut maka pada penelitian ini diangkat 2 model pembelajaran yang akan dibandingkan, yaitu talking stick da nsnowball throwing. Kedua model pembelajaran tersebut akan dibandingkan untuk mengetahui keefektifannya dalam meningkatkan hasil belajarsiswa.

\section{METODE PENELITIAN}

Jenis rancangan penelitian yang digunakan adalah eksperimen semu.Bentuk desain dari eksperimen semu yang digunakan adalah Non-equivalent control grup design.Tempat dan waktu penelitian dilaksanakan adalah di SMA Negeri 1 Alalak.Populasi yang digunakan adalah seluruh siswa-siswi kelas X MIA 1, X MIA 2 dan MIA 3, dan teknik pengambilan sampelnya menggunakan cluster random sampling yaitu mengambil 2 kelas secara acak dengan cara melakukan pengundian sehinggadidapatkankelas X MIA 1(eksperimen 1) dan X MIA 2 (eksperimen 2). Teknik pengumpulan data yaing digunakan adalah soal pilihan ganda. Data yang diperoleh dianalisis menggunakan uji $\mathrm{t}$ dan $\mathrm{N}$ gain.

\section{HASIL DAN PEMBAHASAN}

Uji validitas dilakukan dikelas XI IPA 2 SMA Negeri 1 Alalak dengan jumlah siswa 24 orang. Berdasarkan analisis terhadap hasil validitas tes hasil belajar dengan menggunakan rumus perhitungan $K-R 20$, dari 30 butirsoal yang diujikan,terdapat 24 butir soal yang tidak valid dan 6 butirsoal yang valid. Instrumenhasilbelajar yang di gunakanadalah item soaldengan status valid danuntukbutirsoal yang tidak valid tidakdigunakan. Berdasarkan perhitungan diperoleh reliabilitas keseluruhan butir tes sebesar 0,99 sehinggadapat disimpulkan bahwa butir-butir instrument tersebut memiliki tingkat reliabilitas sangat tinggi.

Data pretest memberikan gambaran kemampuan awal siswa sebelum memperoleh materi pembelajaran. Deskripsi data hasil pretest kelaseksperimen I dan eksperimen II seperti yang terlihat padaTabel 1 berikut:

Tabel 1 Deskripsi data pretest

\begin{tabular}{lcc}
\hline & $\begin{array}{c}\text { KelasEksperimen } \\
\text { I }\end{array}$ & $\begin{array}{c}\text { KelasEksperimen } \\
\text { II }\end{array}$ \\
\hline JumlahSampel & 24 & 24 \\
\hline Skor Minimum & 33,3 & 0 \\
\hline SkorMaksimum & 100 & 100 \\
\hline & 52,74 & 37,47 \\
\hline
\end{tabular}

Berdasarkan tabel1 didapatkan bahwa rata-rata nilai pretest kelaseksperimen I dari 24 siswa sebesar 52,74 dan nilai rata-rata pretest kelas eksperimen II dari 24 siswa sebesar 37,47. 
Deskripsi data hasil posttest kelaseksperimen I dan eksperimen II dapat dilihat pada Tabel2 seperti berikut:

Tabel 2 Deskripsi data postest

\section{Kelas Eksperimen I Kelas Eksperimen II}

\begin{tabular}{lcc}
\hline Jumlah Sampel & 24 & 24 \\
\hline Skor Minimum & 83,3 & 50 \\
\hline Skor Maksimum & 100 & 100 \\
\hline Rata-rata & 90,25 & 79,13 \\
\hline
\end{tabular}

Berdasarkan tabel 2 didapatkan hasil bahwa rata-rata nilai posttest kelas eksperimen I dari 24 siswa sebesar 90,25dan nilai rata-rata posttest kelas eksperimen II dari 24 siswa sebesar 79,13. Uji normalitas dilakukan pad ahasil pretest dan postest pada kelas eksperimen I dankelaseksperimen II, yang bertujuan untuk mengetahui apakah data tersebut berdistribusi normal atau tidak. Hasil uji normalitas pretest dan posttest masing-masing dapat dilihat padaTabel 3 dan 4 .

\section{Tabel 3 Hasil Uji Normalitas pretest}

\begin{tabular}{|l|c|c|c|c|l|}
\hline \multicolumn{1}{|c|}{ Kelas } & N & $\begin{array}{c}\text { L } \\
\text { hitung }\end{array}$ & $\begin{array}{c}\text { L } \\
\text { tabel }\end{array}$ & A & Kesimpulan \\
\hline Eksperimen I & 24 & 0,138 & 0,190 & 0,05 & Normal \\
\hline Eksperimen II & 24 & 0,079 & 0,190 & & Normal \\
\hline
\end{tabular}

Uji normalitas dilakukan dengan menggunakan rumus liliefors, diperoleh $\mathrm{L}_{\text {hitung }}$ untuk kelas Exsperimen I 0,138 dan kelas Exsperimen II 0,079 dari perbandingan $\mathrm{L}_{\text {tabel }}$ yaitu 0,190 yaitu $\mathrm{L}_{\text {hitung }}<\mathrm{L}_{\text {tabel }}$ sehinggaberdistribusi Normal.

\section{Tabel 4 Hasil Uji Normalitas postest}

\begin{tabular}{|l|c|l|l|l|l|}
\hline Kelas & N & L hitung & L tabel & A & Kesimpulan \\
\hline Eksperimen & 24 & 0,167 & 0,190 & 0,05 & Normal \\
I & & & & & \\
\hline $\begin{array}{l}\text { Eksperimen } \\
\text { II }\end{array}$ & 24 & 0,048 & 0,190 & & Normal \\
\hline
\end{tabular}

Uji normalitas dilakukan dengan menggunakan rumus liliefors, diperoleh $\mathrm{L}_{\text {hitung }}$ untuk kelas eksperimen I 0,167 dan kelas eksperimen II 0,048 dari perbandingan $\mathrm{L}_{\text {tabel }}$ yaitu 0,190 yaitu $\mathrm{L}_{\text {hitung }}<\mathrm{L}_{\text {tabel }}$ sehingga berdistribusi normal. Uji homogen dapat dilihat padaTabel 5. 
Tabel 5 Uji Homogenitas

\begin{tabular}{|l|l|l|l|c|c|l}
\hline Jenis data & $\mathbf{N}$ & $\begin{array}{c}\text { Kelas } \\
\text { Experimen I }\end{array}$ & $\begin{array}{c}\text { Kelas } \\
\text { Experimen II }\end{array}$ & $\begin{array}{c}\mathbf{F} \\
\text { Hitun } \\
\mathbf{g}\end{array}$ & $\begin{array}{c}\mathbf{F} \\
\text { tabel } \\
(\boldsymbol{\alpha}=\mathbf{0 , 0 5})\end{array}$ & kesimpulan \\
\hline Pretest & 24 & 16,04 & 18,57 & 1,15 & 2,05 & Homogen \\
\hline Postest & 24 & 8,41 & 15,74 & 1,87 & 2,05 & homogen \\
\hline
\end{tabular}

Berdasarkan Tabel 5 dapat diketahui bahwa perhitungan uji homogenitas dari hasil pretest dan postest kelas eksperimen I dan eksperimen II diperoleh $\mathrm{F}_{\text {hitung }}=1,15$ $<\mathrm{F}_{\text {tabel }}=2,05$ dan postest $\mathrm{F}_{\text {hitung }}=1,87<\mathrm{F}_{\text {tabel }}=2,05$ maka harga $\mathrm{F}_{\text {hitung }}$ signifikan yang berarti bahwa harga varian pada masing-masing kelompok adalah homogen. Oleh karena syarat normalitas dan homogenitas terpenuhi maka, dilakukan uji t.

Uji t yaitu untuk membuktikan hipotesis yang telah diajukan karena data dari kedua kelas berdistribusi normal dan homogen. Hasi luji-t sampel kelas eksperimen I dan kelas eksperimen II dapatdilihatpadaTabel 6.

\section{Tabel 6 hasil uji t posttest}

\begin{tabular}{|l|l|l|l|l|l|l|}
\hline & $\begin{array}{c}\text { Jumlah } \\
\text { siswa }\end{array}$ & SD & $\begin{array}{l}\text { Rata- } \\
\text { rata }\end{array}$ & $\begin{array}{c}\text { T } \\
\text { hitung }\end{array}$ & $\begin{array}{c}\text { T } \\
\text { tabel }\end{array}$ & kesimpulan \\
\hline $\begin{array}{l}\text { Kelas } \\
\text { eksperimen I }\end{array}$ & 24 & 8,41 & 90,25 & & & \\
\hline $\begin{array}{l}\text { Kelas } \\
\text { eksperimen II }\end{array}$ & 24 & 3,96 & 79,13 & 5,883 & 2.064 & Ha diterima \\
\hline
\end{tabular}

Berdasarkan hasil perhitungan data dari postest kelas eksperimen I dan kelas eksperimen II diperoleh $\mathrm{t}_{\text {hitung }} 5,883<\mathrm{t}_{\text {tabel }}$ 2,064 sehingga dapat disimpulkan bahwa $\mathrm{H}_{\mathrm{a}}$ diterima

Data peningkatan merupakan data yang diperoleh dari selisih antarahasil posttest dan pretest yang diperoleh siswa. Analisis data selanjutny aakan dilakukan terhadap data peningkatan (gain). Oleh karenaitu, pada bagian ini akan disajikan terebihdahulutentang data peningkatan (gain) berdasarkankelas.

Tabel 7 Deskripsi data peningkatan

\begin{tabular}{|l|c|c|}
\hline & $\begin{array}{c}\text { KelasEksperimen } \\
\text { I }\end{array}$ & $\begin{array}{c}\text { KelasEksperimen } \\
\text { II }\end{array}$ \\
\hline JumlahSampel & 24 & 24 \\
\hline Skor Minimum & 0,5 & 0 \\
\hline SkorMaksimum & 0,74 & 0,74 \\
\hline Rata-rata & 0,82 & 0,68 \\
\hline
\end{tabular}


Berdasarkan Tabel7 didapatkan hasil bahwa rata-rata peningkatan pada kelas eksperimen I sebesar 0,82 dan rata-rata peningkatan pada kelas eksperimen II sebesar 0,68 . Peningkatan gain eksperimen I termasuk dalam kategori tinggi dan Eksperimen II termasuk dalam kategori sedang. Sehingga dapat dikatakan bahwa penggunaan model snowball throwing lebih efektif dalam meningkatkan hasil belajar siswa daripada model talking stick.

\section{SIMPULAN}

Berdasarkan hasil penelitian maka dapat disimpulkan bahwahasil belajar siswa yang dibelajarkan melalui model snowball throwinglebih tinggi daripada siswa yang dibelajarkan melalui model talking stick.

\section{DAFTAR RUJUKAN}

Suprijono, A. 2013.Cooperative Learning, Teori \& Aplikasi Paikem.Yogyakarta: Pustaka Pelajar.

Susanto, A.2013. Teori Belajar dan Pembelajaran di Sekolah Dasar.Jakarta: PT. KharismaPutra Utama.

Suharsimi, A. 2012.Prosedur Penelitian Suatu Pendekatan Praktik. Jakarta: RinekaCipta.

Unggul, S. 2016. Kimia 1.Untuk SMA/MA Kelas X Berdasarkan Kurikulum 2013. Jakarta: Erlangga.

Huda, Miftahul. 2013. Cooperative Learning, Metode, Teknik Struktur, Dan Model Penerapan. Yogyakarta: PustakaPelajar.

Slavin, E. Robert. 2013. Cooperative Learning Teori, Riset dan Praktik.Bandung: Nusa Media.

Sudjana, N. 2011. Penilaian hasil Proses Belajar Mengajar.Bandung: PT. Remaja Rosdia Karya

Sugiyono. 2011. Metode penelitian Pendidikan: Pendekatan Kuantitatif, Kualitatif, dan $R \& D$. Bandung:Alfabeta. 